\title{
Mandatory Summary Jury Trial: Playing by the Rules?
}

\author{
Charles F. Webber †
}

Every week the clerk of each part turned in a scorecard to Louis Mastroiani, chief administrative judge .... . The scorecard showed how many cases the judge in that part had on his docket and how many he had disposed of that week, through plea bargains, dismissals, and trials. On the wall of the courtroom, over the judge's head, it said IN GOD WE TRUST. On the scorecard, however, it said CASE BACKLOG ANALYSIS, and a judge's effectiveness was rated almost entirely according to CASE BACKLOG ANALYSIS. ${ }^{1}$

Judges have grown accustomed to evaluating their performance by their ability to dispose of cases quickly. ${ }^{2}$ But their efforts to slow the backlog of federal cases have only met with an astronomical increase in the case load of the federal courts. ${ }^{3}$ To address this problem, judges now are turning to methods of alternative dispute resolution ("ADR") and are trying to enlist the help of the parties themselves in making ADR work. Among the techniques judges are exploring is the summary jury trial ("SJT").

The SJT is a procedure in which attorneys present a summary of their cases to an "advisory jury." It is designed to encourage litigants to settle their disputes by illustrating how a trial jury might evaluate the case. The jury's "verdict" is non-binding, and

$†$ B.A. 1987, University of Minnesota; J.D. Candidate 1990, The University of Chicago.

1 Tom Wolfe, The Bonfire of the Vanities 112 (Bantam Books, paperback ed 1987).

2 Judith Resnik, Managerial Judges, 96 Harv L Rev 374, 427 (1982).

3 See generally David S. Clark, Adjudication to Administration: A Statistical Analysis of Federal District Courts in the Twentieth Century, 55 S Cal L Rev 65 (1981). In 1960, 91,693 cases were adjudicated in the federal district courts. By 1970 that number had jumped to 117,254 . In $1980,189,778$ cases were adjudicated in the district courts, representing a 107 percent increase in the twenty years from 1960 to 1980 . Id at 86-88. The number of cases filed in district courts doubled during the 1970s alone. Note, Compelling Alternatives: The Authority of Federal Judges to Order Summary Jury Trial Participation, 57 Fordham L Rev 483, 483 n 2 (1988).

- See Warren E. Burger, Isn't There a Better Way?, 68 ABA J 274 (1982)(advocating ADR). See also Thomas D. Lambros, The Judge's Role in Fostering Voluntary Settlements, 29 Vill L Rev 1363, 1368 (1984). 
the parties are free to disregard the jury's proposed settlement amount. The use of SJT is not controversial when both parties consent. But recently, several judges-understandably eager to reduce their backlog of cases-have required unwilling parties to attend SJTs on pain of sanction and even criminal contempt. ${ }^{5}$ It is this kind of judicial pressure that this Comment examines.

This Comment discusses the use of mandatory SJTs in the federal courts and argues that SJTs should not be forced upon unwilling litigants. Section I examines the SJT process and the current controversy over mandatory SJTs. Section II argues that mandatory SJTs are not supported by either the text of the Federal Rules of Civil Procedure or the intent of those who drafted them, and that at least one provision of the rules appears to preclude the use of mandatory SJTs. Section III evaluates the effects of mandatory SJTs on other aspects of our judicial process, specifically the quality of justice the parties receive in an SJT. This analysis suggests that mandatory SJTs may lead to inaccurate results and an unwarranted pressure on litigants to settle.

\section{The Summary Jury Trial}

\section{A. Description of the Summary Jury Trial}

The SJT was created by Judge Thomas D. Lambros of the Northern District of Ohio. ${ }^{6}$ It is designed for cases where the parties are having difficulty reaching settlement because each overestimates the strength of his own case or, equivalently, underestimates the strength of his opponent's." SJTs reduce this "mutual optimism" by providing the parties with more information about the strength of their cases before proceeding to trial. ${ }^{8}$ SJT's also clarify issues at an earlier stage, thus making a subsequent trial more efficient. ${ }^{9}$

' See, for example, Strandell v Jackson County, Ill., 115 FRD 333, 336 (S D Ill 1987), rev'd 838 F2d 884 (7th Cir 1988) (holding attorney in contempt of court for refusal to attend summary jury trial).

${ }^{6}$ See Thomas D. Lambros, The Summary Jury Trial and Other Alternative Methods of Dispute Resolution, 103 FRD 461 (1984); Thomas D. Lambros and Thomas H. Shunk, The Summary Jury Trial, 29 Cleve St L Rev 43 (1980).

'See Richard A. Posner, Economic Analysis of Law 524 (Little, Brown, 3d ed 1986); Richard A. Posner, An Economic Approach to Legal Procedure and Judicial Administration, 2 J Legal Stud 399, 422-23 (1972).

${ }^{8}$ Posner, Economic Analysis of Law at 525 (cited in note 7). See also William Landes, An Economic Analysis of the Courts, $14 \mathrm{~J} \mathrm{~L} \&$ Econ 61, 66 (1971) (on criminal trials); Lambros, 103 FRD at $468-69$ (cited in note 6).

${ }^{\circ}$ Note, 57 Fordham L Rev at 489 (cited in note 3). 
Most courts use Lambros's formulation of the SJT, in which the judge initiates the SJT process in a pretrial conference with parties who cannot agree on settlement terms. ${ }^{10}$ The judge suggests or requires an SJT, schedules it, and asks the parties to brief the legal issues and submit proposed jury instructions. ${ }^{11}$ Ten potential jurors are obtained from the regular jury roll ${ }^{12}$ for a modified, and abbreviated, voir dire. ${ }^{13}$ Each juror fills out a questionnaire, which is given to the attorneys before examination. ${ }^{14}$ The judge allows each attorney two challenges to the venire, resulting in a six-member jury. ${ }^{15}$ The SJT is not open to the public, and the proceedings usually are not recorded. ${ }^{16}$

The trial judge usually presides at the SJT proceeding, although at least one district court judge sits as a "silent juror" and allows a law clerk to preside. ${ }^{17}$ Each attorney is given a specific amount of time (one hour in Lambros's original formulation) in which to present a summary of his case. No witnesses testify, and objections are discouraged. The attorneys may, however, summarize "anticipated testimony" from reports or depositions. Following the presentations, the jury is given an "abbreviated charge" and deliberates. ${ }^{18}$ The jurors then deliver a consensus verdict and damage recommendation or-if the judge prefers-render verdicts and damage recommendations individually. ${ }^{19}$ After the verdict, the

10 The flexibility of the SJT process makes it difficult to catalogue all the variations district courts may develop in implementing the process. Thomas D. Lambros, The Federal Rules of Civil Procedure: A New Adversarial Model for a New Era, 50 U Pitt L Rev 789, 798-99 (1989). See Gerald L. Maatman, Jr., The Future of Summary Jury Trials in Federal Courts, 21 John Marshall L Rev 455, 463-64 (1988) and notes therein (discussing some of the many variations on the basic theme). The few reported cases discussing the use of the SJT in any detail appear to follow Lambros's formulation with only minor changes. For another judge's account of his experience with the SJT, see S. Arthur Spiegel, Summary Jury Trials, 54 U Cin L Rev 829 (1986).

11 Lambros, 103 FRD at 470 (cited in note 6).

12 See Maatman, 21 John Marshall L Rev at 478 (cited in note 10); and Note, 57 Fordham $L$ Rev at 487 (cited in note 3).

1s Lambros, 103 FRD at 470-71 (cited in note 6).

14 Id at 470 .

15 Id at 471. At least one judge has used a three-person jury. See D. Marie Provine, Settlement Strategies for Federal District Judges 73 n 184 (Federal Judicial Center, 1986).

${ }^{18}$ Lambros, 103 FRD at 471 (cited in note 6). See also Cincinnati Gas and Elec. Co. v General Elec. Co., 854 F2d 900, 902-05 (6th Cir 1988), cert denied $109 \mathrm{~S} \mathrm{Ct} 1171$ (1989) (rejecting a First Amendment challenge to a judge's exclusion of the press from an SJT).

17 Note, 57 Fordham L Rev at $487 \mathrm{n} 22$ (cited in note 3).

18 Lambros, 103 FRD at 471 (cited in note 6).

18 Id. See also Maatman, 21 John Marshall L Rev at 463 n 36-37 (cited in note 10) (discussing variations in the "jury verdicts" in SJTs). It is unclear whether and when the potential jurors are informed their "verdict" will have no binding effect. Compare Maatman, 21 John Marshall L Rev at 463 (cited in note 10) and Note, 57 Fordham L Rev at 487 (cited 
judge often allows the parties to meet with the jurors to discuss their impressions of the case. ${ }^{20}$

Voluntary SJT has been used most frequently in Judge Lambros's Northern District of Ohio, ${ }^{21}$ but has spread to other federal and state courts. ${ }^{22}$ Several federal district courts explicitly provide for SJT in their local rules. The Eastern and Western Districts of Kentucky are illustrative. Their joint rules provide that "[a] judge may, in his discretion, set any civil case for SJT or other alternative method of dispute resolution." ${ }^{23}$ Other courts provide for SJT through standing orders. ${ }^{24}$

\section{B. Differences Between the Summary Jury Trial and Other Forms of Alternative Dispute Resolution}

The term "alternative dispute resolution" has long been used to describe techniques that assist parties in settling their disputes out of court. SJTs are often grouped with the more "traditional" ADR mechanisms of the mini-trial, arbitration, and "rent-ajudge," or private judging. ${ }^{25}$ But significant differences exist.

in note 3), with Richard A. Posner, The Summary Jury Trial and Other Methods of Alternative Dispute Resolution: Some Cautionary Observations, 53 U Chi L Rev 366, 386 (1986)(noting that not telling jurors that their verdict is advisory may undermine the jury system if people discover the ruse, but telling the jurors of the advisory nature of the verdict may adversely affect the process). See also Note, Recent Development-Procedure: Summary Jury Trials in United States District Court, Western District of Oklahoma, 37 Okla L Rev 214, 217 n 16 (1984) (indicating that in contrast to Judge Lambros, some judges in the Western District of Oklahoma do not inform jurors that their verdict is advisory).

${ }^{20}$ See Thomas D. Lambros, The Summary Jury Trial-An Alternative Method of Resolving Disputes, 69 Judicature 286, 289-90 (1986); and Lambros, 29 Vill L Rev at 1377 (cited in note 4).

${ }^{21}$ See Caldwell v Ohio Power Co., 710 F Supp 194, 202 (N D Ohio 1989); Negin v City of Mentor, Ohio, 601 F Supp 1502, 1505 (N D Ohio 1985); Rocco Wine Distributors, Inc. $v$ Pleasant Valley Wine Co., 596 F Supp 617, 621 (N D Ohio 1984); Compressed Gas Corp. $v$ United States Steel Corp., 857 F2d 346, 348 (6th Cir 1988); Erskine v Consolidated Rail Corp., 814 F2d 266, 268 (6th Cir 1987). See generally, M. Daniel Jacoubovitch and Carl M. Moore, Summary Jury Trials in the Northern District of Ohio (Federal Judicial Center, 1982).

${ }^{22}$ See Cincinnati Gas \& Elec. Co. v General Elec. Co., 117 FRD 597, 599 (S D Ohio 1987), aff'd 854 F2d 900 (6th Cir 1988), cert denied 109 S Ct 1171 (1989); Smart v Simonson, 1987 US Dist LEXIS 11079 (N D Ill; December 1, 1987); Lockhart v Patel, 115 FRD 44, 45 (E D Ky 1987). At least two state courts have used SJT. See Bixler v J.C. Penney Co., 376 NW2d 209, 214 (Minn 1985); Estate of Nibert, 1987 WL 102420 (Ohio App 1987).

${ }^{23}$ Local Rule 23, Joint Local Rules for the United States District Courts of the Eastern and Western Districts of Kentucky, reprinted in Comment, Compelled Participation in Summary Jury Trials: A Tale of Two Cases, $77 \mathrm{Ky} \mathrm{L} \mathrm{J} \mathrm{421,} 430$ (1989). See also W D Okla Rule 17(H), cited in Note, 37 Okla L Rev 214, 217 (cited in note 19).

${ }^{24}$ See D Mont Standing Order No 6A, reprinted in Lambros, 103 FRD at 496-98 (cited in note 6).

${ }^{25}$ Lambros, 103 FRD at 466-67 (cited in note 6); Note, 57 Fordham L Rev at $485 \mathrm{n} 9$ 
The mini-trial is a voluntary process in which each party's attorney makes a brief presentation of its case to the litigants-toplevel management officials in cases involving corporations. ${ }^{26} \mathrm{~A}$ "neutral advisor" (usually an attorney or former judge) acts as moderator, and at the conclusion of the presentations tells how she thinks the case would be decided at an actual trial. The parties then sit down without attorneys present and attempt to resolve the dispute. If the parties fail to reach a compromise, the neutral advisor may issue a non-binding opinion discussing the strengths and weaknesses of the parties' positions and predicting the outcome of a courtroom trial. ${ }^{27}$

The SJT also resembles arbitration, the best known of the ADR mechanisms. ${ }^{28}$ The two forms of arbitration-court-annexed and private-generally use the same legal rules that govern ordinary litigation. ${ }^{29}$ Arbitration hearings are abbreviated, adversarial, and informal. Litigants dissatisfied with the result in court-annexed arbitration, like those dissatisfied with an SJT verdict, have a right to trial de novo in a district court..$^{30}$ In private arbitration, however, parties usually do not have this right: they often have previously agreed to accept the results of the arbitration. ${ }^{31}$

The SJT also resembles one of the newest ADR methods: "rent-a-judge" or private judging. ${ }^{32}$ In "rent-a-judge" trials, the parties agree to conduct a private trial before a hired referee, usually a retired judge, and to be bound to some extent by the judge's decision. The parties sometimes agree that the judge will file a report with a federal trial court that may be used to enter judgment.

(cited in note 3). The use of SJT parallels the growing federal court practice of using magistrates to aid in the settlement process. See Provine, Settlement Strategies at 58 (cited in note 15); and Carrie Menkel-Meadow, For and Against Settlement: Uses and Abuses of the Mandatory Settlement Conference, 33 UCLA L Rev 485, 492 (1985).

${ }^{26}$ Stephen B. Goldberg, Eric D. Green, and Frank E. A. Sander, Dispute Resolution 272-75 (Little, Brown, 1985) ("The parties voluntarily agree to conduct a mini-trial.") (emphasis in original).

${ }^{27}$ Id; Lambros, 103 FRD at 467 (cited in note 6).

${ }^{28}$ See Goldberg, et al, Dispute Resolution at 189-225 (cited in note 26); see generally Arnold M. Zack, Grievance Arbitration 265-87 (Lexington Books, 1989). See also the Federal Arbitration Act, 9 USC $\S \S 1-14$ (1982) (governing the use of contractual arbitration in the federal system).

29 Provine, Settlement Strategies at $44-45$ (cited in note 15).

so Id at 48. Litigants who ask for a new trial after court-annexed arbitration take the risk of paying for the arbitration proceeding if they do not obtain a better result at trial.

31 See Goldberg, et al, Dispute Resolution at 189 (cited in note 26) and Provine, Settlement Strategies at 44 (cited in note 15).

${ }^{32}$ See generally Note, The California Rent-A-Judge Experiment: Constitutional and Policy Considerations of Pay-As-You-Go Courts, 94 Harv L Rev 1592 (1981). 
Unlike arbitration, the parties may appeal the referee's decision for errors of law or challenge it as being against the weight of the evidence. $^{33}$

\section{Recent Controversies Over Mandatory Summary Jury Trials}

Although voluntary SJTs and most other forms of ADR have met with general approval, the mandatory SJT is now the focus of heated debate. The most visible controversy began in 1987 when the Southern District of Illinois decided Strandell $v$ Jackson County, Ill. ${ }^{34}$ The plaintiff in Strandell had filed a civil rights action against the county. Chief Judge Foreman, observing that a full jury trial would take five or six weeks to complete and that the parties were "poles apart in terms of settlement," ordered the parties to appear at a non-binding SJT in an effort to settle the action. ${ }^{35}$ The plaintiff's attorney objected to the order, maintaining that it would force him to reveal his trial strategy and case preparation prior to an actual trial on the merits. ${ }^{36}$ The court held the plaintiff's attorney in criminal contempt for his refusal to participate in an SJT.

Judge Foreman gave three bases for his authority to compel an SJT. First, he cited a report of the 1984 Judicial Conference adopting a resolution endorsing the experimental use of SJTs. He pointed out that an initial draft of the resolution had limited the Conference's endorsement of SJTs to cases where the parties consented to its use, but that this language had been omitted without explanation from the final draft of the resolution. Second, Judge Foreman relied on Rule 16 of the Federal Rules of Civil Procedure, which provides that settlement may be discussed at a pretrial conference. He found that although Rule 16 was not designed to force a settlement on unwilling parties, it does permit courts "to order the litigants to engage in a process which will enhance the possibility of fruitful negotiations." ${ }^{\text {"7 }}$ Finally, he pointed to the Speedy Trial Act, ${ }^{38}$ which sets forth stringent time limits for commencing

ss See id at 1592-93; Goldberg, et al, Dispute Resolution at 280-81 (cited in note 26); Lambros, 103 FRD at 466 (cited in note 6).

34115 FRD 333 (S D Ill 1987), rev'd 838 F2d 884 (7th Cir 1988).

3s Id at 334 .

s6 Id. For additional background, see Maatman, 21 John Marshall L Rev at 468 (cited in note 10). Maatman argued the Strandell case before the trial court and the Seventh Circuit on behalf of the sanctioned attorney.

${ }^{37}$ Strandell, 115 FRD at 334-36.

s8 18 USC $\S 3161$ et seq (1982). 
trial in criminal proceedings. ${ }^{39} \mathrm{He}$ noted that the Speedy Trial Act forces courts to clear criminal cases off the dockets before engaging in lengthy civil trials, resulting in long delays for civil cases. ${ }^{40}$ These delays, he concluded, further supported SJT.

On appeal, the Seventh Circuit vacated the order of criminal contempt, holding that a trial court lacks the power to impose sanctions upon an attorney who refuses to appear at an SJT. ${ }^{41}$ The court reasoned that while the pretrial conference provisions of Rule 16 were intended to foster the use of settlement, they were not intended to authorize a mandatory SJT. ${ }^{42}$ Neither the language of Rule 16 nor the intent of its drafters permits a trial judge to "force unwilling parties into settlement negotiations."43

Since Strandell, several district courts have rejected the Seventh Circuit's reasoning and imposed SJTs on unwilling litigants. In Arabian American Oil Co. $v$ Scarfone, the Middle District of Florida concluded that the "obvious purpose and aim of Rule 16" is to permit courts to use any process, including compulsory SJT, in furtherance of "intelligent and effective case management and disposition." ${ }^{44}$ Just four days later, the Eastern District of Kentucky, in McKay v Ashland Oil, Inc., concluded that "a trial court's requiring participation in an SJT is all but expressly authorized by . . . Rule 16." ${ }^{\prime 4}$ The court found most persuasive the Judicial Conference's resolution endorsing the experimental use of SJTs. ${ }^{46}$ Although it recognized that the SJT is not a panacea for all cases, the court concluded that following Strandell would "smother a promising infant in the cradle." The courts' reasoning in Arabian Oil and McKay recently was adopted by the District of Minnesota. In Federal Reserve Bank of Minneapolis v Carey-Canada, Inc., a district court magistrate held that she possessed the power to order an SJT under FRCP 1 and 16, as well as the "in-

30 Strandell, 115 FRD at 334-36. See also note 116.

to Strandell, 115 FRD at 336.

12 Strandell v Jackson County, Ill., 838 F2d 884 (7th Cir 1988).

42 Id at 887.

${ }^{43}$ Id, citing Advisory Committee Notes to Rule 16. See also Charles A. Wright, Arthur A. Miller and Mary K. Kane, 6 Federal Practice and Procedure $\S 1525$ at 343 (West, Supp 1987) ("Wright and Miller").

46 119 FRD 448 (M D Fla 1988) (denying defendant's motion to be excused from participation in an SJT). The court concluded that Strandell was neither "persuasive [nor] binding precedent to this Court." Id at 449.

15 120 FRD 43, 48 (E D Ky 1988) (denying plaintiffs' motion to reconsider imposition of an S.JT).

48 Id.

17 Id at 50. See Comment, $77 \mathrm{Ky} \mathrm{L} \mathrm{J}$ at $438-40$ (cited in note 23) (concluding that Strandell and McKay can be reconciled because of differences in the facts of each case). 
herent powers" doctrine. ${ }^{48}$ In sum, no reported case from a federal district or appellate court supports Strandell, ${ }^{49}$ and commentators have been equally vocal in rejecting it. ${ }^{50}$

In order to show how the reasoning of Strandell's critics is flawed, this Comment will analyze the authority of a federal court to compel SJTs. In particular, the next section will examine three commonly cited sources of authority: the Federal Rules of Civil Procedure, the court's inherent powers, and a report of the United States Judicial Conference.

\section{Federal Court Power to Compel Mandatory Summary JuRY TRIaLS}

\section{A. The Federal Rules of Civil Procedure}

Most judges and commentators who favor mandatory SJTs rely upon various provisions of the Federal Rules of Civil Procedure. The debate has focused on Rules 16, 83, 1, and 68. Close examination reveals that these four provisions fail to support mandatory SJTs.

\section{Rule 16.}

Rule 16 is the fountainhead of federal courts' power to manage pretrial procedure, giving trial courts great power to direct the pretrial phases of litigation. Rule 16(a) allows courts to direct pretrial conferences and specifies that pretrial conferences can be used to

48123 FRD 603, 604 (D Minn 1988). The magistrate explicitly rejected Strandell. Id at 606.

48 The District of Massachusetts recently stated in a footnote unnecessary to the disposition of the case that a trial court has power to order a summary jury trial under Rule 16. Home Owners Funding Corp. of America v Century Bank, 695 F Supp 1343, 1347 n 3 (D Mass 1988). Somewhat questionable, however, is the court's statement that while litigants can be compelled to participate in an SJT, they must agree to other ADR mechanisms such as trial before a magistrate or "rent-a-judge." Id. The court offered no explanation for the different treatments of SJT and other ADR techniques it cited. See also Cincinnati Gas \& Elec. Co. $v$ General Elec. Co., 117 FRD 597 (S D Ohio 1987), aff'd on other grounds, 854 F2d 900 (6th Cir 1988), cert denied, $109 \mathrm{~S}$ Ct 1171 (1989) (trial court has inherent power to conduct SJT as a settlement procedure); Lockhart v Patel, 115 FRD 44 (E D Ky 1987) (striking defendant's pleadings is a proper sanction for failure to send representative from home office to attend settlement conference). Both Cincinnati Gas and Lockhart relied upon the trial court opinion in Strandell while the appeal to the Seventh Circuit was pending. No federal appeals court other than the Seventh Circuit has addressed the issue.

${ }^{80}$ See Lambros, 50 U Pitt L Rev at 804 (cited in note 10)(asserting that Rule 16 calls for "intensive management and participation in litigation by the court, to the extent. . . of compelling ADR"). See also Comment, $77 \mathrm{Ky} \mathrm{L} \mathrm{J}$ at 439-40 (cited in note 23); Note, 57 Fordham L Rev at 491 (cited in note 3). 
facilitate settlement of the case..$^{81}$ Rule 16(c) states that "settlement or the use of extrajudicial procedures" are appropriate topics of conversation at a pretrial conference. ${ }^{52}$ Given that a trial judge can order participants to attend pretrial conference in order to encourage settlement through extrajudicial procedures, it is not unreasonable to infer, as so many courts and commentators have, that a judge can require a mandatory SJT.

There are, however, persuasive textual arguments that Rule 16 rejects the mandatory SJT by negative implication. Although Rule 16(a) allows a judge to direct the parties to attend a pretrial conference for the purpose of settlement, it does not give courts express power to mandate any procedure for settlement purposes. Furthermore, Rule 16(c) states that the conference participants "may consider" the use of extrajudicial procedures, not that the court "may direct" such procedures. The use of the precatory "may consider" in the same rule as the mandatory "may direct" suggests that the drafters intended to give judges less power to compel extrajudicial proceedings than to compel appearance at a pretrial conference.

In addition, Rule 16(c)(7) authorizes discussion at a pretrial conference of "extrajudicial" procedures for exploring settlement. Most commentators agree that SJTs are not extrajudicial. ${ }^{53}$ They are "conducted inside the courtroom of a federal courthouse, before an Article III judge, and with jurors selected from the court's master jury wheel who are paid from congressionally apportioned funds."

si Rule 16(a) provides:

In any action, the court may in its discretion direct the attorneys for the parties and any unrepresented parties to appear before it for a conference or conferences before trial for such purposes as (1) expediting the disposition of the action ... and; (5) facilitating the settlement of the case.

s2 Rule 16(c) states:

The participants at any conference under this rule may consider and take action with respect to ... (7) the possibility of settlement or the use of extrajudicial procedures to resolve the dispute ... and (11) such other matters as may aid in the disposition of the action.

${ }^{53}$ See Posner, 53 U Chi L Rev at 385-86 (cited in note 19) (finding that the word "extrajudicial" implies that the subsection does not sanction the use of judicial procedures of dispute resolution such as the SJT). See also Robert E. Keeton, The Function of Local Rules and the Tension with Uniformity, 50 U Pitt L Rev 853, 858 (1989) (contrasting SJT with extrajudicial consideration of settlement); and Case Comment, Cincinnati Gas \& Electric Co. v. General Electric Co.: Extinguishing the Light on Summary Jury Trials, 49 Ohio St L J 1453, 1466-68 (1989) (finding that SJT is very close to a full but abbreviated trial because of the great expenditure of judicial resources).

s4 Maatman, 21 John Marshall L Rev at 480 (cited in note 10). 
niques at all.55 But if it does, the presence of the word "extrajudicial" suggests that the drafters intended to sanction only ADR methods outside the courtroom, such as mediation and arbitration. ${ }^{\circ 6}$

The Advisory Committee's Notes to Rule 16 provide only a little more information about the purpose and intent of the rule. The purpose of subdivision (c) was to improve the planning and management of litigation by expanding the 1938 conception of subjects that may be discussed at a pretrial conference. ${ }^{57}$ Clause (7), for example, was added to recognize that "it has become commonplace to discuss settlement at pretrial conferences" and to facilitate settlement at an early stage of the litigation. ${ }^{58}$ Along with other notes to Rule 16, these unambiguously "pro-settlement" statements have led some to conclude that the Rule's primary purpose is to broaden a judge's pretrial management powers. ${ }^{59}$

It is erroneous, however, to read the Advisory Committee Notes as if they solely encourage settlement, for they also reflect concern for parties not wishing to settle. The Committee noted, for example:

Although it is not the purpose of Rule 16(c)(7) to impose settlement negotiations on unwilling litigants, it is believed that providing a neutral forum for discussing the subject might foster it ... [t] the rule does not make settlement conferences mandatory because they would be a waste of time in many cases. $^{60}$

In addition to specifically refusing to require courts to conduct settlement conferences, the Advisory Committee also refused to require courts to hold pretrial conferences. ${ }^{61}$

Moreover, although the Committee's comments endorse settlement broadly, they also frequently refer to the more modest goals

${ }^{55}$ Keeton, 50 U Pitt L Rev at 858 (cited in note 53).

${ }^{8 B}$ See Maatman, $21 \mathrm{John}$ Marshall L Rev at 478 (cited in note 10).

s7 FRCP 16(c) Advisory Committee Notes (1983).

s8 Id.

"8 See, for example, Matter of Sanction of Baker, 744 F2d 1438, 1440 (10th Cir 1984); and Robert B. McKay, Rule 16 and Alternative Dispute Resolution, 63 Notre Dame L Rev 818,823 (1988).

Bo FRCP 16(c) Advisory Committee Notes (1983) (emphasis added), citing James W. Moore, Federal Practice § 16.17 at 16-54 (Matthew Bender, 1971); 6 Wright and Miller § 1522 at 334 (cited in note 43 ).

B1 The introduction the the Advisory Committee's 1983 Notes on Rule 16 state: "[A]lthough scheduling and pretrial conferences are encouraged in appropriate cases, they are not mandated." 
of removing impediments to settlement and defining the issues. ${ }^{62}$ The Committee's goal of providing a "neutral forum" for settlement discussions indicates that it merely intended to give judges the opportunity to discuss settlement with the parties at the pretrial conference should they so desire. In other words, the drafters' primary concern may have been to resolve any doubts as to whether settlement is an appropriate subject of pretrial discussion. $^{63}$ The pretrial conference provision appears to be primarily informational, not coercive in nature. ${ }^{64}$

Rule 16 certainly gives judges power to do more than just provide a room (their chambers) for the parties to discuss settlement. It is quite plausible that Rule 16 gives judges the power to ensure that the parties have thought seriously about settlement, but stops short of conferring power to require the parties to take specific steps towards settlement. More specifically, under Rule 16 a judge may convene a pretrial conference, question the parties on steps taken toward settlement, ascertain what additional steps they plan to take, ensure that the parties have considered key facts in the case that might affect the decision whether to settle, and help the parties settle the case if they are open to compromise-maybe even suggesting a voluntary SJT as an innovative way of exploring settlement..$^{85}$ In other words, the judge can ensure that the parties have seriously considered such negotiations, but cannot require that they enter into them.

This reading of Rule 16 is consistent with the drafters' intent not "to impose settlement negotiations on unwilling litigants," and recognizes that litigants may have good reasons not to settle. For example, a party may wish to reap the benefits of res judicata, which precludes other parties from bringing future claims that are identical to the present claim. This requires a court judgment; a favorable settlement will not suffice. The drafters of Rule 16 surely respected the fact that litigants have absolutely no duty to bargain

62 See FRCP 16(c) Advisory Committee Notes (1983), stating that Rule 16(c)(1) was designed to "confirm the court's power to identify the ... real issues prior to trial, thereby saving time and expense for everyone."

ss See FRCP 16(a) Advisory Committee Notes (1983), stating that "the amendment explicitly recognizes some of the objectives of pretrial conferences and the powers that many courts already have assumed."

ot See Maatman, 21 John Marshall L Rev at 472 (cited in note 10), citing J.F. Edwards Const. Co. v Anderson Safeway Guard Rail Corp., 542 F2d 1318, 1323 (7th Cir 1976).

${ }^{65}$ See Provine, Settlement Strategies at 71 (cited in note 15) (reporting that some federal judges try to "sell" the litigants on the virtues of SJT).

${ }^{68}$ FRCP 16(c)(7) Advisory Committee Notes (1983). 
over settlement, and may insist on "their day in court." "67

If compelling an SJT is analogous to convening a conference to discuss the possibility of settlement, then the authority to do so might fit within the boundaries of judicial intervention under Rule 16(a). But the analogy does not hold. The parties in an SJT are submitting the facts of their dispute to a neutral arbitrator for his non-binding decision. The outcome of the SJT-the amount of the "jury verdict"-almost certainly will be used by one of the parties as a basis for a settlement offer. Taking steps to put a "dollar value" on a case surpasses mere discussion about settlement negotiations; it approximates a settlement negotiation itself. ${ }^{68} \mathrm{~A}$ judge who requires an appearance at an SJT is forcing the party to enter into what corresponds to settlement negotiations. This practice was rejected by the drafters of Rule 16 .

Finally, interpreting Rule 16 to authorize judges solely to facilitate and not to coerce settlement is supported by subsequent congressional proposals to amend the rule. The Alternative Dispute Resolution Promotion Act of $1986,{ }^{69}$ as passed by the Senate, would have required attorneys to advise their clients of ADR options and to file notice with the court certifying that the clients were properly notified. ${ }^{70}$ The House version was similar. ${ }^{71}$ The proposed legislation expressly provided that an attorney "shall ... advise the party of the existence and availability of alternative dispute resolution options, including extra-judicial proceedings such

${ }^{67}$ See National Ass'n of Government Employees, Inc. $v$ National Federation of Federal Employees, 844 F2d 216, 223 (5th Cir 1988) (failure to compromise a case does not constitute grounds for imposing sanctions); Del Rio v Northern Blower Co., 574 F2d 23, 26 (1st Cir 1978) (there is no duty to settle a case); G. Heileman Brewing Co., Inc. v Joseph Oat Corp., 871 F2d 648, 658 (Coffey dissenting), 664 (Easterbrook dissenting) (7th Cir 1989) (Rule 16 does not grant district court power to compel represented party's presence at settlement conference).

${ }^{88}$ One of the foremost judicial proponents of mandatory SJTs, Judge Bertelsman, explicitly described SJTs as "settlement negotiations" in U.S. $v$ Kentucky Utilities Co., 124 FRD 146, 153 n 7 (E D Ky 1989) (court can take steps to maintain confidentiality of settlement negotiations like SJT). See also Cincinnati Gas, 854 F2d at 904-05; and Case Comment, 49 Ohio St L J at 1463 (cited in note 53); but see Note, 57 Fordham L Rev at 494-95 (cited in note 3) (arguing that an SJT, whether voluntary or mandatory, is not a settlement negotiation, but merely a technique to foster settlement).

69 Litigation Abuse Reform Act of 1986, Hearings on S 2038 before the Senate Committee on the Judiciary, 99th Cong, 2d Sess (February 3, 1986), in 132 Cong Rec S 848 (February 3, 1986). See also Litigation Abuse Reform Act of 1986, Hearings on S 2038 before the Senate Committee on the Judiciary, 99th Cong, 2d Sess (1986).

${ }^{70}$ See S 2038, §§ 3(a)-(b) (cited in note 69). See also Maatman, 21 John Marshall L Rev at $474 \mathrm{n} 88$ (cited in note 10).

${ }^{71}$ See Alternative Dispute Resolution Promotion Act of 1987, HR 473, 100th Cong, 1st Sess (January 7, 1987), in 133 Cong Rec H 157 (January 7, 1987). 
as mini-trials, and ... court supervised arbitration, and SJT proceedings."72 However, the proposed legislation did not give judges the option of making an SJT mandatory. In fact, the proposed bill stated that each attorney must "indicat[e] whether his client will agree to one or more of the alternative dispute resolution techniques," "73 and provided that the court could enter an order only "[i]n the event all parties to an action agree to proceed with one or more" of the procedures. ${ }^{74}$

Thus, even when Congress expressly considered promoting ADR techniques through Rule 16 , it proposed a system that would be informational (the attorney need only attest that she has informed the client of ADR techniques) and not coercive. If the legislation is passed, Congress will leave the ultimate choice to the parties, without any judicial interference. ${ }^{75}$

\section{Rules 83 and 1.}

Rule 16 is most directly applicable to the question of mandatory SJTs, but some courts also rely upon Rules 83 and 1 . Rule 83 gives a federal district court the power to "make and amend rules governing its practice not inconsistent with these rules." The rule is not an independent source of federal judicial power; it conditions the validity of a local court rule upon its conformity with the Federal Rules of Civil Procedure as a whole. Courts have held local rules invalid under Rule 83 if they conflict with the language or intent of one of the federal rules. ${ }^{77}$ Thus, a local rule need not conflict with the plain words of a federal rule in order to be impermissible under Rule 83 .

Similar reasoning can be used to reject as a justification for

${ }^{72} \mathrm{~S} 2038 \S 3(\mathrm{a})$ (cited in note 69 ). Note that the proposed bill includes the minitrial-but not the SJT or court-supervised arbitration-as an example of an extra-judicial proceeding (the phrase "extra-judicial proceedings such as mini-trials" is separated from "summary jury trial proceedings"). See text accompanying notes 53-56.

${ }^{73} \mathrm{~S} 2038$ \& 3(a) (cited in note 69) (emphasis added).

"Id (emphasis added).

${ }^{75}$ The proposal to amend Rule 16 can be classified as "post-enactment legislative history." The weight to be given post-enactment legislative history is somewhat controversial. Contrast Patricia Wald, Some Observations on the Use of Legislative History in the 1981 Supreme Court Term, 68 Iowa L Rev 195, 205 (1983); with Andrus v Shell Oil Company, 446 US 657, 666 n 8 (1980).

78 FRCP 83 (emphasis added). For an example of a court relying on a local rule in mandating an SJT, see McKay, 120 FRD at 44 (citing Local Rule 23, Joint Local Rules for the United States District Courts of the Eastern and Western Districts of Kentucky).

${ }^{77}$ See, for example, McCargo $v$ Hedrick, 545 F2d 393, 400-02 (4th Cir 1976) (holding a local rule invalid because it violated the spirit of Rule 16). 
mandatory SJTs Rule 1's call for the "just, speedy, and inexpensive determination of every action." courts and commentators notwithstanding, the word "speedy" is not necessarily the most important in Rule 1, to be read to trump the remaining language of the rule-and the specific dictates of the eighty-five rules that follow. ${ }^{79}$ The stated purpose of the federal rules is to promote justice. ${ }^{80}$ One could even argue that the placement of the word "just" before the word "speedy" in Rule 1 indicates the drafters' intent that justice prevail over speed. In any event, even if Rule 1 gives courts the discretion to resolve cases justly and speedily, the trial judge must use his discretion wisely. ${ }^{81}$ This means that he cannot ignore the context of a federal rule or apply it without considering its relation to the other federal rules. ${ }^{82}$ Thus, if Rule 16 does not give courts the power to compel SJT, Rule 1, like Rule 83 , should not be used to achieve the same end. ${ }^{83}$

\section{Rule 68.}

Rule 68 is the only provision in the Federal Rules of Civil Procedure that penalizes a party for failing to settle a case. It provides that if a defendant makes a timely offer of settlement and the plaintiff rejects it, and if the plaintiff later obtains a judgment for less than the offered settlement amount, the plaintiff cannot recover post-offer attorney's fees from the defendant. ${ }^{84}$ Rule 68 ,

28 For use of this rationale see Strandell, 115 FRD at 335-36; Note, 57 Fordham L Rev at 497 (cited in note 3); Lambros, 103 FRD at 469 (cited in note 6).

78 See Note, 57 Fordham L Rev at 493 and n 77 (cited in note 3), citing Real v Hogan, 828 F2d 58, 63 (1st Cir 1987).

80 See 6 Wright and Miller $\S 1029$ at 116 (cited in note 43); Ohio v Arthur Andersen \& Co., 570 F2d 370 (10th Cir 1978).

${ }^{81}$ See, for example, 6 Wright and Miller $\$ 1029$ at 120 (cited in note 43).

${ }^{82}$ Id. See also Coyne-Delany Co. $v$ Capital Dev. Bd. of Illinois, 717 F2d 385, 392 (7th Cir 1983); Gangemi v Moor, 268 F Supp 19, 21-22 (D Del 1967); Note, Judicial Authority in the Settlement of Federal Civil Cases, 42 Wash \& Lee L Rev 171, 177 (1985).

${ }^{83}$ For arguments that Rule 1 gives judges broad authority over trial procedure, see Note, 57 Fordham L Rev at 493 and $n 77$ (cited in note 3); Arabian American Oil Co. $v$ Scarfone, 119 FRD 448, 449 (M D Fla 1988); and Note, 42 Wash \& Lee L Rev at 174 (cited in note 82 ).

84 FRCP 68 provides, in pertinent part:

At any time more than 10 days before the trial begins, a party defending against a claim may serve upon the adverse party an offer to allow judgment to be taken against the defending party for the money or property or to the effect specified in the offer, with costs then accrued. . . An offer not accepted [within 10 days] shall be deemed withdrawn and evidence thereof is not admissible except in a proceeding to determine costs. If the judgment finally obtained by the offeree is not more favorable than the offer, the offeree must pay the costs incurred after the making of the offer.

Rule 68 by its terms does not apply in cases where the defendant prevails. See generally 
then, provides an element of compulsion that Rule 16 lacks: the rule tells plaintiffs that resisting reasonable settlement offers may be costly.

The question is how far this policy of encouraging settlement extends. It can be argued that Rule 68 indicates a broad endorsement of settlement even in cases where it does not expressly apply, and that the rule sanctions mandatory SJT because it encourages settlement. ${ }^{88}$ But Rule 68 can also be read as a denial of a federal court's power to compel an SJT. This is evident from the limited scope of the rule itself. The Rule 68 cost-shifting apparatus does not apply to every case that is litigated in the federal courts; it applies only to offers by defendants, and allows shifting of attorney's fees only when it is provided for by the underlying statute. ${ }^{86}$

Courts should not extend the policy behind a legal rule beyond the scope provided in the rule itself. ${ }^{87}$ Mandatory SJTs clearly lie outside the explicit authority conferred by Rule 68 . In fact, when courts impose mandatory SJT they may even contravene Congress's intent, extending the pro-settlement policy beyond the boundaries set by the rule. As the Supreme Court recently recognized, "it frustrates rather than effectuates legislative intent simplistically to assume that whatever furthers the statute's primary objective must be the law." 88 Rule 68 , then, becomes a powerful argument against the proposition that mandatory SJT is consistent with the Federal Rules of Civil Procedure. The drafters of the federal rules provided in Rule 68 a certain amount of incentive for parties to settle; they went no further.

In addition, Rule 68's expression of preference for settlement furnishes no basis for inferring approval of judicially imposed settlement proceedings. Rule 68 is self-executing, and does not confer any power on a judge. ${ }^{80}$ Thus, it is somewhat troublesome to read Rule 68 as a justification for mandatory SJTs. In short, although Rule 68 does encourage settlement, it is a limited rule with a care-

Delta Air Lines, Inc. $v$ August, 450 US 346 (1981). The Supreme Court most recently expressed its approval of Rule 68's tendency to promote settlement in Marek $v$ Chesny, 473 US 1 (1985) (upholding the application of Rule 68 against a civil rights plaintiff).

${ }^{85}$ See, for example, Note, The Proposed Amendment to Federal Rule of Civil Procedure 68: Toughening the Sanctions, 70 Iowa L Rev 237, 238-39 (1984) (arguing that Rule 68 is a means of reducing litigation and encouraging out-of-court settlement).

so See Delta Air Lines, 450 US at 352; Marek, 473 US at 8.

37 See Frank H. Easterbrook, Statutes' Domains, 50 U Chi L Rev 533 (1983).

so Rodriguez v United States, 480 US 522, 526 (1987) (per curiam).

89 FRCP 68 provides that "the offeree must pay the costs incurred after the making of the offer" (emphasis added). See also Waters $v$ Heublein, Inc., 485 F Supp 110, 113 (N D Cal 1979) (holding that a court does not have discretion under Rule 68). 
fully defined domain. Like Rules 16, 83, and 1, Rule 68 does not give a federal judge the power to compel SJTs. Without the authority of the federal rules, a judge must rely on some other source for such a power.

\section{B. The Inherent Powers of a Federal Court}

Some courts and commentators base a trial judge's power to compel attendance at SJTs on a court's "inherent power to manage its docket." These "inherent powers" are different from those expressly provided in the Federal Rules of Civil Procedure, and are traditionally thought to derive "from the very nature of the judicial system."

The Seventh Circuit recently stated, in a sharply divided en banc opinion in G. Heileman Brewing Co., Inc. $v$ Joseph Oat Corp.,$^{92}$ that federal courts have broad inherent power to manage their dockets. The court held that even if Rule 16 does not explicitly authorize a district court to order litigants represented by counsel to appear personally at a pretrial conference, a trial court may issue such an order on the basis of its inherent powers. ${ }^{93}$ The court described the inherent power to take action in a procedural context as "governed not by rule or statute but by the control necessarily vested in courts to manage their own affairs so as to achieve the orderly and expeditious disposition of cases."

As conceived by the Seventh Circuit, courts' inherent powers existed prior to enactment of the federal rules, and under the common law enabled courts to make rules for themselves. ${ }^{95}$ The federal rules merely carved out and codified those inherent powers devoted to rulemaking. ${ }^{98}$ Those areas that were not codified, the ar-

${ }^{\text {9o }}$ See Note, 57 Fordham L Rev at 495-99 (cited in note 3); Lambros, 103 FRD at 469 (cited in note 6). See also McKay, 120 FRD at 48; Strandell, 115 FRD at 335.

${ }^{81}$ See Note, 42 Wash \& Lee L Rev at 179 (cited in note 82), citing United States $v$ Hudson and Goodwin, 11 US (7 Cranch) 32, 33 (1812).

${ }^{92} 871$ F2d 648 (7th Cir 1989) (en banc). The Seventh Circuit's opinion reverses a prior panel opinion. The vote was 6 to 5 , with the inherent powers question proving one of the most contentious points. Id at 657 (Posner dissenting), 659 (Coffey dissenting), 663 (Easterbrook dissenting), 665 (Ripple dissenting), 666 (Manion dissenting).

${ }^{83}$ Id at 652 .

${ }^{94}$ Id at 651, quoting Link $v$ Wabash R.R., 370 US 626, 630-31 (1962) (holding that federal courts have an inherent power "of ancient origin" to assess sanctions in response to abusive litigation). 1988).

${ }^{95}$ See Soo Line R. Co. v Escanaba \& Lake Superior R. Co., 840 F2d 546, 551 (7th Cir

${ }^{88}$ See Sibbach $v$ Wilson \& Co., 312 US 1, 14 (1940), rejecting a defendant's arguments that powers the parties had before the enactment of the Federal Rules of Civil Procedure are retained undiminished. The Court indicated that the Federal Rules erased the old eq- 
gument goes, still exist undiminished and may be exercised to the extent they remain in harmony with the federal rules. ${ }^{97}$ In short, the Federal Rules of Civil Procedure do not completely describe the powers of the federal courts. ${ }^{88}$

Though the Supreme Court has recognized the existence of some inherent powers in the courts, the scope of the inherent powers not covered by the Federal Rules is traditionally viewed as quite narrow. These remaining powers grow out of well-acknowledged historical roots and apply only in "narrowly defined circumstances." A court's inherent powers are limited to those "necessary to the exercise of all others," 100 necessary for a court "to preserve its own existence," 101 and "absolutely essential" for the functioning of the judiciary. ${ }^{102}$ They encompass "an extremely narrow range of authority involving activity so fundamental to the essence of a court as a constitutional tribunal that to divest the court of absolute command within this sphere is really to render practically meaningless the terms 'court' and 'judicial power." "103 Most of the courts invoking inherent powers have done so in order to sanction those who abuse the judicial process. ${ }^{104}$

There are at least three reasons why the inherent powers are construed so narrowly. First, the powers are very difficult to define. Even the Heileman majority conceded that a court's inherent powers are undefined and "not frequently documented." 105 In addition,

uity powers of the parties and recast them in codified form.

97 Id.

's Stuckey v Northern Propane Gas Co., 874 F2d 1563, 1573 (11th Cir 1989); HMG Property Investors, Inc. v Parque Indus. Rio Canas, Inc., 847 F2d 908, 915 (1st Cir 1988).

92 Roadway Express v Piper, 447 US 752, 765 (1980). See also Link, 370 US at 629.

${ }^{100}$ United States $v$ Hudson and Goodwin, 11 US (7 Cranch) 32-33 (1812).

101 Id.

${ }^{102}$ Levine $v$ United States, 362 US 610, 616 (1960).

${ }^{10 s}$ Eash v Riggins Trucking Inc., 757 F2d 557, 562 (3d Cir 1985) (emphasis added).

${ }^{104}$ Eash, 757 F2d at 561. See Roadway Express, 447 US at 764-67; (sanctions for use of legal process solely to harass); Link, 370 US at 629-33 (federal court has inherent power to dismiss case sua sponte for failure to prosecute); Young $v$ United States ex rel Vuitton et Fils S.A., 481 US 787 (1987), and Levine, 362 US at 615 (punish for contempt); Hazel-Atlas Glass Co. $v$ Hartford-Empire Co., 322 US 238, 244 (1944) (equitable power to set aside judgments obtained through fraud); Universal Oil Products Co. v Root Refining Co., 328 US 575,580 (1946) (sanctions for the perpetration of frauds on the court). One commentator has written that this branch of the inherent powers amounts to "docket control," or the ability to sanction parties for being "lazy." See Note, 57 Fordham L Rev at 497 (cited in note 3). However, the cases relied upon by that commentator, Roadway Express and Link, involved sanctions for abuse of the judicial process, and not mere laziness.

${ }^{105}$ Heileman, 871 F2d at 651, citing Brockton Savings Bank, 771 F2d 5, 11 (1st Cir. 1985). Inherent powers have been described as "nebulous" and "shadowy" even by those who support mandatory SJT. See Note, 57 Fordham L Rev at 495 (cited in note 3); Steven B. Burbank, Sanctions in the Proposed Amendments to the Federal Rules of Civil Proce- 
inherent powers are troublesome because they are shielded from democratic control. For this reason, the Supreme Court has counseled that they be exercised only "with restraint and discretion."106 Finally, there may be constitutional limitations on the scope of inherent powers. Even the power to sanction parties for contempt rests rather uneasily upon the provisions of Article III, ${ }^{107}$ and extensions of the inherent powers beyond the power to sanction must be viewed with suspicion.

Moreover, as the Seventh Circuit explicitly recognized in Heileman and Strandell, a court's inherent power, like its Rule 83 power to make local court rules, is limited to those cases where the power sought to be exercised does not conflict with the other Federal Rules of Civil Procedure. ${ }^{108}$ In crafting the rules, Congress and the Supreme Court carefully balanced the need for efficiency against the need to protect individual rights. ${ }^{109}$ District courts cannot use inherent authority to formulate procedural rules at odds with the Constitution or the Federal Rules of Civil Procedure.110 Such exercise of unspecified powers "would confer on the judiciary discretionary power to disregard the considered limitations of the law it is charged with enforcing." 111

dure: Some Questions About Power, 11 Hofstra L Rev 997, 1004 (1983).

108 See Roadway Express, 447 US at 764.

${ }^{107}$ See Young, 481 US at 816-17 (Scalia concurring) (arguing that judicial prosecution of parties who disregard court orders is not an exercise of the Article III judicial power to act as a neutral adjudicator). But see In re Martin-Trigona, 737 F2d 1254, 1261 (2d Cir 1984), stating that courts must have the power to protect themselves from vexatious conduct that impairs their ability to carry out Article III functions, and cannot be dependent upon another branch of government for that power.

${ }^{108}$ See Heileman, 871 F2d at 652; Strandell, 838 F2d at 886.

109 See S Rep No 1744, 85th Cong, 2d Sess (June 23, 1958), in 1958 USCCAN 3023, 3026 (stating that the Federal Rules of Civil Procedure are carefully balanced in order to recognize both "the need for expedition of cases and the protection of individual rights"); Strandell, 838 F2d at 886 (federal rules reflect delicate balancing process between Congress and the Court). See generally Sibbach, 312 US at 14-16 for discussion of the balancing process between Congress and the Court. See also Bank of Nova Scotia v United States, $108 \mathrm{~S}$ Ct 2369, 2374 (1988) (district court may not dismiss an indictment for prosecutorial misconduct when Congress and the Court struck balance in Federal Rule of Criminal Procedure 52 permitting harmless error). This balancing is the joint responsibility of the legislative and judicial branches of government. See also Heileman, $871 \mathrm{~F} 2 \mathrm{~d}$ at 659 (Coffey dissenting), noting the similarity of the Court-Congress balancing under criminal cases like Bank of Nova Scotia and civil cases like Strandell. See the Rules Enabling Act, 28 USCA $\S \S 2072$, 2073, 2074 (West 1966 \& Supp 1988) (giving the Supreme Court power to prescribe general rules of procedure).

${ }^{110}$ Bank of Nova Scotia, $108 \mathrm{~S} \mathrm{Ct}$ at 2374, citing United States $v$ Hasting, 461 US 499, 505 (1983). In Bank of Nova Scotia, the Court dealt with a federal court's exercise of its "supervisory power," the criminal law equivalent of a court's "inherent power" in civil cases. See also Heileman, 871 F2d at 659 (Coffey dissenting).

11 United States v Payner, 447 US 727, 737 (1980). 
Courts sometimes attribute the authority to compel SJT to a novel inherent power deriving from "necessity" or convenience. ${ }^{112}$ But the Supreme Court has rebuffed attempts by district court judges to exercise wide-ranging power just because it is convenient to do so. In Thermtron Products, Inc. v Hermansdorfer, ${ }^{113}$ for example, the federal district judge had unilaterally remanded the case back to state court, citing his crowded docket and the fact that there was not enough time to try the case. ${ }^{114}$ The Supreme Court held that the federal judge erred in remanding the action on grounds not listed in 28 USC § 1447(c). ${ }^{115}$ The Court rejected arguments that the trial court's docket was too crowded to keep the case, reasoning that "an otherwise properly removed action may no more be remanded because the district court considers itself too busy to try it than an action properly filed in the federal court in the first instance may be dismissed or referred to state courts for such reason."116

Thus, arguments relying upon a court's inherent powers must recognize the limitations of those powers. It strains credulity to assert that the power to compel parties to take steps in settling a case is indispensable or "fundamental to the essence of a court."117 Concerns of convenience and efficiency do not justify creation of a new inherent power that is undefined, shielded from democratic control, and unsanctioned by the congressional-judicial balancing process of the Federal Rules of Civil Procedure. Thus, the inherent powers doctrine does not justify mandatory SJTs.

\section{Judicial Conference Approval of Mandatory SJTs}

To bolster their authority to impose mandatory SJTs, a few

112 Eash, 757 F2d at 563.

113423 US 336 (1976).

114 Id at 339 .

118 Id at 345. 28 USC § 1447(c) (1982) provides in part: "If at any time before final judgment it appears that the case was removed improvidently and without jurisdiction, the district court shall remand the case. ..."

116 Thermtron, 423 US at 344. As noted, the lower court in Thermtron based its remand on crowded dockets and lack of trial time. This reasoning parallels Strandell, where the trial court based its decision to compel an SJT in part on an interpretation of the Speedy Trial Act, 18 USC $\$ 3161$ et seq (1982). See text at notes $39-40$. The Strandell court failed to notice, however, that other factors may contribute to the slow movement of the civil docket, such as the rules of discovery but the mere fact that there are some things that slow down the civil docket does not suggest mandatory SJT is a logical necessity. Furthermore, the drafters of the Speedy Trial Act must have been aware that it would delay civil litigation; their failure to provide for an analogous speedy trial act for civil cases suggests they did not find the Speedy Trial Act's effect on the civil docket a serious matter.

${ }^{117}$ Eash, 757 F2d at 562. 
courts have pointed to modifications in the initial draft of a report of the 1984 Judicial Conference. The draft endorsed SJTs, but "only with the voluntary consent of the parties."118 In the final draft of the resolution, however, the "voluntary consent" language was dropped without explanation. ${ }^{119}$ The trial courts in both $M c^{-}$ Kay and Strandell found this omission persuasive, inferring that the conference viewed mandatory SJTs as consistent with the federal rules. ${ }^{120}$

The Judicial Conference has never issued an explicit endorsement of mandatory SJTs, however, and the McKay and Strandell courts overlooked one of the most plausible explanations for the omission: the conference simply did not wish to take a position on the touchy topic of mandatory SJTs. Another explanation for the omission of language in a later draft is lack of confidence in the clarity of the omitted language. Neither court explored these possibilities.

The views of a committee of the Judicial Conference, moreover, are only persuasive and not binding authority. ${ }^{121}$ Other judicial committees have rejected mandatory SJTs. ${ }^{122}$ Judicial Conference pronouncements have no binding force because the handful of judges participating in the conference are not promulgating rules. Thus, their comments cannot be given the same weight as comments by the drafters of Rule $16 .{ }^{123}$ Even if the Judicial Conference were acting in an administrative rulemaking capacity, the Supreme Court has held that the conclusions of judges acting in a rulemaking capacity are not entitled to the same deference as their

11 The original draft provided that "the Judicial Conference endorses the use of summary jury trials, only with the voluntary consent of the parties, as a potentially effective means of promoting the fair and equitable settlement of lengthy civil jury trials." Report of Judicial Conference Committee on the Operation of the Jury System Agenda G-13 4 (GPO, 1984).

118 The final draft omitted the clause "only with the voluntary consent of the parties." Reports of the Proceedings of the Judicial Conference of the United States 88 (GPO, 1984). There was, however, no explanation for the omission of the language. On the absence of a documented explanation for the change, see Maatman, 21 John Marshall L Rev at 457 \& $n 11$ (cited in note 10 ).

${ }^{120}$ See Strandell, 115 FRD at 334-35; McKay, 120 FRD at 48. See also Lambros, 50 U Pitt L Rev at 803 (cited in note 10) (finding the Judicial Conference report significant).

${ }^{121}$ For a description of the composition and function of the Judicial Conference, see 28 USCA § 331 (West, 1968 and Supp 1988).

${ }^{122}$ The Judicial Conference of the Second Circuit rejected mandatory ADR techniques including SJT in its 1986 report. Second Circuit Committee on the Pretrial Phase of Civil Litigation, Final Report, reprinted at 115 FRD 453, 457 (1986). Neither Strandell nor McKay mentioned this rejection of mandatory SJT.

${ }^{123}$ See Maatman, $21 \mathrm{John}$ Marshall L Rev at $473 \mathrm{n} 81$ (cited in note 10). 
decisions on questions of law. ${ }^{124}$ Therefore, the conference's views are no more persuasive than a trial judge's decision to impose an SJT in a real case. In short, the Judicial Conference resolution is at most a guide to what a handful of respected judges think about the question. ${ }^{125}$

\section{Mandatory Summary Jury Trial and the Judicial Process}

An SJT is not a costless procedure. Indeed, SJT imposes monetary costs on litigants, as well as costs in the form of pressure to settle for the amount of the SJT "verdict." If the SJT yields inaccurate results, such costs are unwarranted. This section briefly examines the overall quality and effectiveness of mandatory SJTs.

\section{A. Lack of Evidentiary and Procedural Safeguards in the SJT}

One danger in forcing parties to appear at an SJT is that the result may rest on inaccurate, or at least inadequately tested, facts. Several factors contribute to this danger: (1) the usual rules of evidence may not apply at an SJT; (2) witnesses are not permitted; and (3) voir dire is greatly abbreviated. This section examines each factor in turn.

Where, as in our adversarial system, the parties are responsible for finding and presenting facts to the court, a critical control mechanism is the ability of the opposing party to challenge the facts placed into evidence. But at least one court has stated that the Federal Rules of Evidence do not apply in an SJT. ${ }^{126}$ If taken to an extreme, this lack of evidentiary protection could result in the introduction of irrelevant evidence. ${ }^{127}$

Although Judge Lambros's formulation of the SJT incorpo-

${ }^{124}$ See Mississippi Publishing Co. v Murphree, 326 US 438, 444 (1946) (fact that Supreme Court promulgates rules as recommended by the Advisory Committee does not foreclose consideration of their validity, meaning, or consistency). See also Grand Bahama Petroleum Co., Ltd. v Canadian Transportation Agencies, Ltd., 450 F Supp 447, 450 (W D Wash 1978).

${ }^{125}$ Most judges on the Judicial Conference are trial court judges, and therefore are likely to endorse a proposal that is expected to speed up the civil docket.

${ }^{128}$ Cincinnati Gas, 854 F2d at 904. But Lambros's original formulation of the SJT provided that only evidence admissible at trial would be allowed, although he discouraged objections. Lambros, 103 FRD at 471 (cited in note 6). See also Case Comment, 49 Ohio St L J at 1454 (cited in note 53) (only admissible evidence permitted at SJT).

${ }^{127}$ See FRE 402 and 403. Judge Lambros writes that the judge can always incorporate basic rules of evidence into the SJT in order to prevent the introduction of improper evidence. But he does not indicate which rules he would incorporate as "basic." See Lambros and Shunk, 29 Cleve St L Rev at 51 (cited in note 6). 
rates the basic rules of evidence, he discourages formal objections. ${ }^{128}$ One attorney who participated in an SJT voiced concern over his inability to object:

The inability to object ... gave the plaintiffs carte blanche to present whatever arguments and versions of the facts they chose, regardless of whether they would have been admissible at trial. Plaintiffs' [presentation] bore no resemblance to courtroom testimony. They had the look and tone of investigative journalism and concentrated on creating emotion rather than addressing the facts. . . Rebuttal time also gave the plaintiffs. . . an obvious advantage, since they could have the last word without fear of objection or surrebuttal. ${ }^{129}$

Thus, even though a conscientious judge may be on the lookout for attempts to introduce patently inadmissible evidence, the flexibility and informality exalted by proponents of the SJT make possible serious transgressions of the rules of evidence.

When evidence is introduced at an SJT that would be inadmissable at a regular trial, the results a "jury" reaches based on that information are suspect. ${ }^{\mathbf{1 3 0}}$ To be sure, the parties may discount their faith in the jury's recommendation to reflect the fact that the jury did not get the "true picture." If this happens, however, the SJT loses some or most of its value as an informationproducing mechanism. This problem could be avoided, of course, by requiring that the Federal Rules of Evidence apply at all SJTs, but such a requirement would only make the SJT more complex and would probably make the process longer and less desirable as a voluntary means of alternative dispute resolution.

A second factor leading to inaccurate results is the prohibition of witnesses at SJTs. ${ }^{131}$ Instead, attorneys may summarize anticipated "witness testimony" from reports or depositions. ${ }^{132}$ These statements cannot be challenged by cross-examination, and the SJT jury cannot evaluate the demeanor or credibility of the witnesses; consequently, two of the most valued methods of discerning the truth at trial are removed. ${ }^{133}$ In cases where witness credibility

128 Lambros, 103 FRD at 471 (cited in note 6).

${ }^{129}$ Clifford J. Zatz, Summary Jury Trial: The Settlement of a Toxic Tort Case, 2 Toxics L Rptr 929, 933-34 (1988).

130 See Maatman, 21 John Marshall $L$ Rev at 482-83 (cited in note 10).

131 Lambros, 103 FRD at 471 (cited in note 6).

132 See text at note 18.

133 See Resnik, 96 Harv L Rev at 408 n 137 (cited in note 2). See also Lon L. Fuller, The Adversary System, in Harold J. Berman, ed, Talks on American Law 30, 39 (Vintage, 
is an issue, then, the jury's advisory verdict in an SJT could be especially inaccurate. ${ }^{134}$

A third factor that could result in inaccurate SJT results is abbreviated voir dire. In Judge Lambros's original formulation of the SJT, only ten potential jurors are selected, and counsel are permitted only two challenges each. ${ }^{135}$ The attorneys rest their challenges only on the "basic information" contained in questionnaires that each potential juror completes. These questionnaires are normally prepared by the court. ${ }^{136}$ Sometimes voir dire takes only 15 minutes. ${ }^{137}$ Unless the parties are given some role in selecting the questions that will be asked on this form, they are not as free to elicit information from the decision makers as they would have been in the context of a regular jury trial. In short, although hailed as a method of "relieving counsel and the court from having to obtain the information from each potential juror during voir dire," ${ }^{138}$ the abbreviated process of juror selection severely limits the amount of information available to the attorneys about the "jurors" who hear the case.

\section{B. Effects of the Mandatory SJT on the Unwilling Litigant}

As the above section indicates, the jury presiding over an SJT draws its conclusions from a record that is composed largely of claims untested by the opposing party. Proponents of the mandatory SJT may argue that we need not worry about the lack of fidelity to the protections of a full jury trial, and any resulting unwarranted pressure to settle, since a party is free to reject the advisory SJT verdict and pursue the case to a full trial with the usual evidentiary and procedural safeguards. These arguments, however, overestimate the parties' "freedom" to ignore the SJT verdict. An unwilling party may in fact be under great pressure to settle for the amount of the SJT verdict. Mandatory SJTs also create practical difficulties for parties unwilling to settle, such as the

rev ed 1971) (discussing an American Bar Association study showing that without adversary presentation of facts, judges and jurors have a tendency to reach conclusions at an early stage of the litigation and adhere to those conclusions even though conflicting considerations later develop).

${ }^{234}$ See Comment, $77 \mathrm{Ky} \mathrm{L} \mathrm{J} \mathrm{at} 437$ (cited in note 23).

135 See Lambros, 103 FRD at 471 (cited in note 6). Lambros uses a six-member jury. At least one judge has held an SJT using only three jurors. See Provine, Settlement Strategies at $73 \mathrm{n} 184$ (cited in note 15).

${ }^{136}$ Lambros, 103 FRD at 470, 490-91 (cited in note 6).

${ }^{137}$ Maatman, 21 John Marshall L Rev at 462 (cited in note 10).

${ }^{138}$ Lambros, 103 FRD at 470 (cited in note 6). 
loss of strategic options and the additional cost of preparing for an SJT.

It is usually the case that one party (" $A$ ") will be under mounting pressure to settle by the end of the SJT. The judge may be pushing for settlement on the basis of the jury's findings in an SJT. A's opponent may also be making settlement offers based on the results of the SJT-offers which, if rejected, may preclude A from recovering post-offer costs under Rule $68 .^{139}$ The judge's perceptions, the opponent's offer, and even A's modified opinion of his own case, however, are based on possibly erroneous evaluations of the strength of A's case. Thus, the pressure on A may be unwarranted.

The potential inaccuracies of an SJT are especially troublesome for corporate litigants because an SJT verdict that is substantial relative to a firm's assets may be material information that must be disclosed to shareholders. ${ }^{140}$ This danger further pressures the firm to settle rather than continue on to trial. In this setting, "the summary trial becomes the real trial rather than just an aid to settlement. It is a very cheap real trial and that is all to the good, but it may also be an unreliable method of adjudicating a substantial dispute."141

Parties that resist these pressures to settle face other disadvantages as well. Mandatory SJTs may prevent each party from keeping its strategies quiet until an actual trial on the merits. It is true that courts usually require the parties to exchange witness lists and summaries of testimony before trial. Since a summary jury trial is based on facts disclosed by discovery and is meant to be a synopsis of the actual trial, it is hard to see how anything would be disclosed by a summary jury trial that would not be disclosed before the real trial anyway. Judges therefore usually doubt attorneys' claims that there are still "secrets" that legitimately can be kept until the day of trial. Although the advent of liberal discovery rules has outmoded the "sporting" theory of litigation, ${ }^{142}$ an

${ }^{139}$ See text accompanying notes 84-89.

${ }^{140}$ See Posner, 53 U Chi L Rev at 387 (cited in note 19). Note, however, that Posner described this argument as tenuous. See also $\S 10(b)$ of the Securities Exchange Act of 1934, 15 USC $\S 78 \mathrm{j}(\mathrm{b})(1982)$ governing employment of deceptive devices in connection with the purchase or sale of any security. It is also possible that stock prices would fluctuate if such information "leaked" to investors.

141 Posner, 53 U Chi L Rev at 387 (cited in note 19).

142 "Trial by ambush has long since been eliminated from the federal system." McKay, 120 FRD at 48; Federal Reserve Bank of Minneapolis v Carey-Canada, Inc., 123 FRD 603, 606 (D Minn 1988). 
attorney may still keep some "secrets" prior to trial. In fact, the Federal Rules of Civil Procedure affirmatively protect some elements of a trial. Rule 26(b)(3), for example, protects against disclosure of an attorney's mental impressions and legal strategies. ${ }^{143}$ An SJT exposes all of this information. If the parties do not settle after an SJT, the attorneys will go to trial with a new understanding of the case, and new information about their opponent's trial strategy. ${ }^{144}$ This information would ordinarily have been protected prior to trial by the Federal Rules of Civil Procedure.

Moreover, not every judge waits for the completion of discovery to order an SJT. This poses two problems. First, it may increase the inaccuracy of the SJT "verdict" if the parties are not fully prepared or informed or about the case. Second, it may reward the lazy or slow party at the expense of the diligent one. In Strandell, for example, the plaintiffs' attorneys had engaged in voluminous discovery before the court ordered an SJT; the defendants had done virtually none. ${ }^{145}$ The trial court had at one point denied the defendant's motion to compel production of the statements of several of the plaintiffs' witnesses on the grounds of privilege. ${ }^{146}$ This left the plaintiffs with legitimate "secrets" even after pretrial discovery. But the mandatory SJT that the court ordered later would have effectively eliminated the statements' secrecy and privilege, since the plaintiffs would have been under a great deal of pressure to present her best case-which necessarily included the privileged statements. One of the plaintiffs' attorneys described this "Hobson's choice" as follows:

[The] order compelling participation in the [SJT] placed plaintiffs' counsel in a position of adopting one line of strategy different from that of a full trial on the merits. Plaintiffs' counsel would have had to confine their presentation to conclusory arguments of the defendants' alleged liability in order to avoid the risk of irreparable harm and injury to their case, which would be caused by revealing the privileged witness statements in the summary jury trial. Since defense counsel had failed to undertake any discovery with respect to witnesses, defense counsel therefore would become the recipient

143 "[T]he court shall protect against disclosure of the mental impressions, conclusions, opinions, or legal theories of an attorney. . . " FRCP 26(b)(3).

1s Maatman, $21 \mathrm{John}$ Marshall L Rev at 472 (cited in note 10).

14s Id at 468.

146 Strandell v Jackson County, Ill., 7 Fed R Serv 3d 715 (S D Ill 1986); Maatman, 21 John Marshall L Rev at 468 (cited in note 10). 
of the specifics of testimony in the [SJT] that they had not bothered to investigate. ${ }^{\mathbf{1 4 7}}$

Even if discovery is complete, an SJT aids a party who has done shoddy discovery, as the defendants in Strandell apparently did.

Finally, supporters of mandatory SJTs often overlook the additional monetary costs that SJTs impose on the parties. When settlement fails, a litigant forced to endure an SJT before getting a "day in court" must prepare twice for one trial. ${ }^{148}$ This increases the costs of the eventual trial, and may persuade some parties to settle earlier than they would have otherwise in order to avoid the duplicate expenses. While it could be argued that the extra preparation helps the attorneys become organized earlier in the litigation, ${ }^{149}$ a cost-conscious litigant probably will not appreciate the extra court-ordered preparation. It also is not clear why judges should force attorneys to be prepared for trial before the actual trial date. The imposition of these additional costs is particularly unwarranted when one of the parties has a legitimate reason for litigating the case once the SJT is finished..$^{150}$

\section{Empirical Evidence of the Effects of the SJT: Will It Work?}

A large piece of the puzzle that is missing in any analysis of the SJT (and more importantly of the mandatory SJT) is its effectiveness in increasing settlement rates. Proponents of the mandatory SJT often slight the fact that it consumes public resources. ${ }^{151}$ Many SJTs last longer than the "ideal" one-half day proposed by Judge Lambros ${ }^{152}$ and extend to several days. ${ }^{153}$ It could be argued that the cost savings from cases that do settle after an SJT would more than offset the extra costs associated with going through an SJT and then a later trial if the case does not settle. Such an argument, however, completely lacks empirical sup-

147 Maatman, 21 John Marshall L Rev at 475 (emphasis added).

${ }^{148}$ See Note, 57 Fordham L Rev at $489-90$ (cited in note 3) (some attorneys resent mandatory SJT because it forces double preparation).

14 See, for example, id at 490; Spiegel, 54 U Cin L Rev at 835 (cited in note 10).

150 See text at notes 66-67.

151 See Posner, 53 U Chi L Rev at 373, 382 (cited in note 19).

152 See Lambros, 103 FRD at 469, 471 (cited in note 6).

${ }^{163}$ See Zatz, 2 Toxics $L$ Rptr at 930 (cited in note 129), reporting that a summary jury trial in a toxic torts case took three days to complete. The "jury" was divided into two groups, each giving separate verdicts. One jury rendered a verdict of $\$ 2.8$ million for the plaintiffs, the second rendered a verdict of $\$ 300,000$ for the plaintiffs. See also Richard A. Enslen, Alternative Dispute Resolution: Summary Jury Trial in a Toxic Tort Case, 2 Toxics L Rptr 1015 (1988); and Maatman, 21 John Marshall L Rev at 464-67 (cited in note 10). 
port. ${ }^{154}$ Judge Richard Posner has commented on the noticeable lack of empirical data supporting either side of the argument, stating his lack of enthusiasm for the usual "anecdotes, glowing testimonials, confident assertions, [and] appeals to intuition" advanced to support the effectiveness of the SJT. ${ }^{185}$ The importance of resolving such arguments accentuates the need for empirical information on the rather complex questions involved.

Some commentators have offered evidence of the effectiveness of SJTs in increasing settlement rates. Judge Lambros, for example, maintains that the use of SJTs has led to a ninety percent settlement rate in the Northern District of Ohio: ${ }^{156}$ an impressive figure, but most studies show that in fact over ninety percent of all cases settle before trial. ${ }^{157}$ Thus, Lambros's statistics may stand for the proposition that the SJT does nothing to increase the settlement rate.

In fact, some studies show that pretrial efforts at encouraging settlement usually waste judicial resources. One of the first studies of mandatory pretrial conferences showed that they "reduced the efficiency of the court by consuming judges' time in handling conferences rather than in trying cases."158 The early studies also showed that cases submitted to mandatory pretrial conference had roughly the same settlement rate as those cases that did not go to mandatory pretrial conference. ${ }^{169}$ This conclusion tends to confirm Judge Posner's fear that the SJT wastes judicial resources because it is too lavish with the judge's time. ${ }^{160}$ Judge Posner conducted his own concededly "crude" study of districts in which SJTs are used. He found that there was no support for the conclusion that SJTs increase judicial efficiency. ${ }^{\mathbf{1 6 1}}$

In sum, if parties reach settlement with equal frequency under mandatory and voluntary settlement conditions, judicial settle-

154 See, for example, Menkel-Meadow, 33 UCLA L Rev at 486-87, 492-98 (cited in note 25) (suggesting that claims regarding the efficacy of any technique of alternative dispute resolution lack empirical support).

155 Posner, 53 U Chi L Rev at 367 (cited in note 19).

136 Lambros, $50 \mathrm{U}$ Pitt $\mathrm{L}$ Rev at 800 (cited in note 10).

167 William W. Schwarzer, The Federal Rules, The Adversary Process, and Discovery Reform, 50 U Pitt L Rev 703, 707-08 (1989); and Menkel-Meadow, 33 UCLA L Rev at 502 (cited in note 25).

${ }^{158}$ Menkel-Meadow, 33 UCLA L Rev at 493.

150 Id.

${ }^{160}$ Posner, 53 U Chi L Rev at 382 (cited in note 19).

161 Id at 374-85. For other attempts to verify the effects of SJTs, see Provine, Settlement Strategies at 75-76 (cited in note 15). For other attempts to find empirical evidence regarding the effectiveness of pretrial techniques in general, see Jacoubovitch and Moore, Summary Jury Trials in the Northern District of Ohio at 7, 11-13, 17 (cited in note 21). 
ment management must be an inefficient waste of judicial resources. ${ }^{162}$ In addition, mandatory settlement procedures will cost litigants more than they save in litigation fees. ${ }^{163}$ The uncertainty surrounding the efficacy of pretrial settlement techniques counsels that they not be imposed against the will of the parties.

\section{CONCLUSION}

This Comment has argued that the Federal Rules of Civil Procedure, when read in conjunction with the comments of the drafters, do not support the use of mandatory SJTs. In addition, the presence of Rule 68 suggests that Congress went only so far in authorizing the application of pressure on litigants to settle their case, but no further. Resort to the "inherent powers of the judiciary" is of little help: the inherent powers have always been construed narrowly and have never been used to allow a court to force a party to consider resolving a dispute in a particular way. Mandatory SJT is also likely to lead to inaccurate results because normal checks in our judicial system, such as the right to crossexamination and other evidentiary rules, are missing from the SJT.

The goal of reducing the strain on the federal judicial system is a laudable one. Judges are expected to cure a backlog of cases that they did nothing to create or aggravate. But reducing the strain on the federal courts should not involve dangerous experimentation with techniques that are unsupported by the Federal Rules of Civil Procedure and unlikely to be effective in practice.

${ }^{162}$ See Menkel-Meadow, 33 UCLA L Rev at 494 (cited in note 25).

${ }^{183}$ Id at 512. 